\title{
Migration in the UK: moving beyond numbers
}

\author{
David Robinson* \\ Sheffield Hallam University
}

\begin{abstract}
Unprecedented numbers of migrants have arrived into the UK since the early 1990s. Heated debate has surrounded this new phase of immigration. The government has been accused of loosing control of the borders and stories have abounded about 'bogus' asylum seekers and economic migrants gaining access to resources at the expense of British citizens. The political response has been to talk tough on numbers and securing the border. This rhetoric fails to acknowledge that migration is a reality of the networked society we now live in and that large numbers of migrants will continue to arrive in the UK. The real challenge is managing the process of migration effectively in order to minimise the impact on all concerned. To this end, three new policy priorities are proposed: ending the administrative detention of children for immigration control; tackling the destitution of asylum seekers and refugees; and helping local communities to manage the challenges posed by new immigration.
\end{abstract}

Keywords: Migration, asylum, refugees, New Labour, Conservative.

\section{Introduction}

The New Labour government presided over a phase of migration unparalleled in UK history. Between 1997 and 2008, more than six million people migrated to the UK and net migration topped two million (ONS, 2010). During this period public perception hardened around the view that society is paying a heavy price for the increased inflow of migrants. The government was portrayed as 'loosing control of the country's borders', a perception reinforced by press reports, ranging from rolling coverage of the efforts of residents of the Red Cross camp at Sangette, Calais to enter the UK, through to the furore about foreign prisoners. The country was depicted as awash with 'bogus' asylum seekers and illegal workers and stories abounded about foreign nationals exploiting the generosity of British welfare state and securing access to resources (health care, housing, employment) at the expense of British Citizens. By 2006, 44 per cent of the population considered immigration to be one of the most worrying issues facing the UK, compared to less than five per cent in the mid-1990s (IPSOS MORI, 2006). 


\section{p. 15. Migration in the UK: Moving Beyond Numbers}

Stung by criticism that it was failing to secure the border and manage the inflow of foreign nationals into the UK, New Labour introduced no less than seven Parliamentary Acts on asylum and immigration between 1997 and 2009. Initially, reforms focused on improving the efficiency of the asylum system and tackling what was reported to be the "significant abuse of the asylum system by those who are economic migrants but claim to be persecuted" (Home Office, 2005: 17). Attention then turned to managing migration and maximising its potential to serve the national economy, while continuing to reform the asylum system. Following the arrival of large numbers of workers from the European Union Accession States, the emphasis switched toward 'selective admission', involving the introduction of an Australian-style points system for migrant workers from outside the EU, and promoting integration through a new pathway to citizenship. New Labour's tone also became more populist, Gordon Brown responding to a series of unofficial strikes over the awarding of jobs on a number of UK construction projects to European workers with a call for "British jobs for British workers".

The Conservative party, under David Cameron, was initially reluctant to speak on immigration, apparently concerned that the Party's hard line on the issue had contributed to their defeat in the 2005 general election. When David Cameron eventually set out the Party's position, the focus was squarely on numbers. A Conservative government, it was declared, would put a cap on immigration, reducing "immigration to the levels of the 1990s - tens of thousands a year, instead of the hundreds of thousands a year under Labour" (Conservative Party, 2010). This would be achieved through the introduction of an annual limit on the numbers of non-EU economic migrants allowed to work in the UK, taking into consideration the effects a rising population has on our public services and local communities. Illegal migration would also be limited through the introduction of new rules to tighten up the student visa system (already 'tightened' by the Labour government) and a proposed dedicated Border Police Force to "crack down on illegal immigration and people trafficking" (Conservative Party, 2010).

\section{The Reality of Migration}

The position of both parties is founded on the premise that managing migration is, first and foremost, about managing the border in a bid to reduce the number of migrants entering the UK. Talking tough on numbers might play well with the public, but it denies the reality that international migration is an established process of the networked, globalised world we live in. Large numbers of migrants will continue to arrive in the UK. Some will stay for a short time, others will make the UK their home. No government, whatever its political hue, is going to alter this reality. There are at least three reasons why not.

First, the government has no control over one of the largest migration streams into the UK. More than 40 per cent of the six million long term international migrants who arrived in the UK between 1997 and 2008 (some 2.5 million people) were UK or EU citizens, who had the legal right to enter and settle in the country. Unless a future government intends to renegotiate the terms of the UK's membership of the EU and withdraw from the single market and the associated commitment to the free movement of labour, putting the UK's membership of the EU in doubt, any promise to bring net migration down to "tends of thousands rather than hundreds of thousands" is either naive or disingenuous.

Second, the UK ratified the UN Convention on Refugees in 1954 and accepted a moral and legal duty to protect individuals who have fled persecution because of their 
race, religion, nationality or membership of a particular social or political group. No mainstream UK political party is suggesting reneging on this commitment. The sad reality is that wars, conflict and persecution will continue to force people to flee their homelands. Some of these people will exercise the right to claim asylum in the UK. Those that do will be entitled to the full protection of the law while their claim is being considered.

Third, no government can afford to turn off the supply of foreign workers. The UK economy has become dependent upon labour migration for a flexible workforce and low wage inflation. Both the Labour and Conservative Party tacitly accept this fact. New Labour have consistently championed the importance of migrant labour to increasing economic flexibility and efficiency, arguing that "without migration, our rate of economic growth would be much lower" (Home Office, 2005: 13). Thus, although the points-based immigration system has introduced higher earnings and qualification thresholds and longer advertising periods for vacancies before they can be filled by a migrant, no proposals were forthcoming for the system to be used to make deep cuts in the flow of skilled migrants to the UK. The Conservative Party, meanwhile, talks about putting an "annual limit on the numbers of non-EU economic migrants allowed to work here", but at the same time remains committed to "continue to attract the brightest and the best people to the UK" (Conservative Party, 2010).

\section{Priorities for Action}

Migration to the UK will ebb and flow with the economic cycle and as wars come and go, but will remain a constant feature of life in Britain. Policy should acknowledge this reality, look beyond the moral panic, hysteria and hyperbole that has surrounded the issue in popular debate and discussion and seek to manage migration as fairly and effectively as possible. To this end, here are three urgent priorities for action.

First, the government should follow the advice of the Children's Commissioner for England and end the administrative detention of children for immigration control. Each year some two thousand children are detained for administrative purposes for immigration control, the majority being held in Yarl's Wood Immigration Removal Centre in Bedfordshire. Official figures suggest that the average length of time in detention for children and young people is 14 days, but the Commissioner reports that some children are held for much longer periods. Detailed concerns raised by the Children's Commissioner (2009) about the consequences of detention on children include disquiet about what happens to children and families during arrest, the emotional impact of detention and the damage of being in detention to the health and well-being of children. A follow up report noted improvements in practices but reiterated the "contention that arrest and detention are inherently damaging to children, and that Yarl's Wood is no place for a child" (The Children's Commissioner, 2010: 12).

Second, government should urgently address the destitution that asylum seekers and refugees are experiencing at every stage of the asylum process. The scale of this problem is difficult to quantify, but a number of local studies suggest it is widespread and significant. A study in Birmingham in 2005, for example, estimated that there were between 1,000 and 2,000 destitute asylum seekers and refugees in the city (Malfait and Scott-Flynn, 2005) and a survey of destitute asylum seekers visiting four support agencies in Leeds in April-May 2009 recorded 232 destitute individuals with 11 adult dependents and 30 children (Lewis, 2009). Causal factors are reported to include the limiting of support, procedural delay and administrative error in the asylum process, and gaps and inflexibility in support (ICAR, 2006). The consequences can include a lack of shelter and sleeping rough, problems with food and clothing, limited 
access to healthcare which can impact on physical and mental health, and exposure to exploitative and dangerous situations. In light of this evidence, the Joint House of Lords and House of Commons Committee on The Treatment of Asylum Seekers (2007) concluded that by refusing permission for asylum seekers to work and operating a system of support which results in widespread destitution, the Government's treatment of asylum seekers in a number of cases breaches Article 3 of the European Convention on Human Rights threshold of inhuman and degrading treatment.

Third, government needs to more actively assist statutory agencies and local communities in effected areas to manage and mediate the local impacts of new immigration. There is little doubt that the scale, nature and scope of contemporary migration has the potential to drive change at the neighbourhood level, posing challenges for new immigrants, settled residents and service providers alike. Reported problems include concerns about who is getting access to what resources and why; problems for local service providers in the context of rapid population change and increasing diversity and a shifting profile of need; concerns about the material conditions of new residents and their exclusion from key services; and emerging tensions and conflict between new arrivals and settled populations.

Local communities have been abandoned to manage these challenges alone. The government has committed to do little other than listen to people's fears and concerns about the local impacts and consequences of new immigration (Robinson, 2007), circulate good practice and practical advice on how to manage change (CLG, 2009a) and allocate $£ 70$ million to a Migration Impacts Fund to manage the "short term pressures [of migration] on local public services including councils, schools, NHS and the police...for the benefit of the whole community" (CLG, 2009b). Meanwhile, local authorities complain that official population estimates fail to record the true number of migrants settling in their area resulting in an inadequate financial settlement with the Treasury and consequent problems maintaining levels of service provision and meeting local needs (Doward and McKenna, 2007; Robinson, 2007).

Seizing the initiative, the British National Party (BNP) has set about actively propagating myths about new immigrants gaining access to scarce local resources at the expense of British citizens and successfully forged new political alliances among people who perceive themselves and their life chances to be harmed by new immigration (Johns, et al., 2005; 2006; Robinson, 2010). Resentment within the settled population has been exacerbated, local tensions have been heightened, new immigrants and migrants have become the targets of abuse, harassment and violence, and the far-right has secured new authority and power (Robinson, 2010). This populist discourse needs to be challenged, in words and deeds. Migration has local impacts. These need to be recognised, without debate retreating into well worn stereotypes about immigrants as 'scroungers' and scare stories about cultural and material loss in the face of immigration. They also need to be managed, a challenge that demands that government steps forward and actively assists effected areas, that are often already struggling with the consequences of economic decline and public service cuts.

* Correspondence Address: David Robinson, Centre for Regional Economic and Social Research, Sheffield Hallam University, Howard Street, Sheffield, S1 1WB. Email: d.robinson@shu.ac.uk. 


\section{References}

Independent Asylum Commission (2008) Deserving Dignity. The Third Report of Conclusions and Recommendations. How to Improve How we Treat People Seeking Sanctuary. (http://www.independentasylumcommission.org.uk/)

CLG (2009a) Managing the Impacts of Migration: Improvements and Innovations. London: Department for Communities and Local Government.

CLG (2009b) Press release Government announces $£ 70 m$ fund to support communities with migration. (http://www.communities.gov.uk/news/corporate $\angle 1180107)$

Conservative Party (2010) Where we Stand: Immigration. (http://www.conservatives. com/Policy/Where we stand/Immigration.aspx)

Doward, J. and McKenna (2007) Immigration figures 'are false'. The Observer, 29 April. (http://www.guardian.co.uk/society/2007/apr/29/asylum.politics)

Home Office (2005) Controlling our Borders: Making Migration Work for Britain. London: The Stationery Office.

House of Lords, House of Commons Joint Committee on Human Rights (2007) The Treatment of Asylum Seekers. Tenth Report of Session 2006-07. London: The Stationery Office Limited.

ICAR (2006) Destitution amongst Refugees and Asylum Seekers in the UK. (http://www.icar.org.uk/?lid=6575)

Ipsos Mori, 2006 Ipsos Global Citizens Monitor May (Ipsos Mori, London) (http://www.ipsos-mori.com/ assets/internationalsocialtrends/istu-may06.pdf)

John, P., Margetts, H., Rowland, D. and Weir, S. (2005) The far right in London: A challenge for local democracy? York: Joseph Rowntree Reform Trust.

John, P., Margetts, H., Rowland, D. and Weir, S. (2006) The BNP: The roots of its appeal. Democratic Audit, Human Rights Centre: University of Essex.

Lewis, H. (2009) Still destitute: A Worsening Problem for Refused Asylum Seekers. York: Joseph Rowntree Charitable Trust.

Malfait, R. and Scott-Flynn, N. (2005) Destitution of Asylum-Seekers and Refugees in Birmingham. Birmingham Churches Together and the Church Urban Fund.

ONS (2010) Long-Term International Migration. Time Series 1991 to 2008. (http://www.statistics.gov.uk/StatBase/Product.asp?vlnk=507)

Robinson, D. (2007) European Union accession state migrants in social housing in England. People, Place and Policy Online, 1, 3, 98-111.

Robinson, D. (2010) New immigrants and migrants in social housing in Britain: discursive themes and lived realities. Policy and Politics, 38, 1, 57-77.

The Children's Commissioner for England (2009) The Arrest and Detention of Children Subject to Immigrant Control: A report following the Children's Commissioner for England's visit to Yarl's Wood Immigration Removal Centre. (http://www.11million.org.uk/)

The Children's Commissioner for England (2010) The Children's Commissioner for England's follow up report to: The arrest and detention of children subject to immigration control. (http://www.11million.org.uk/) 